\title{
Population Control and Women Health
}

\section{Yunis Khushi*}

International Relations Department, Lahore Garrison University, Pakistan

*Corresponding Author: Yunis Khushi, International Relations Department, Lahore Garrison University, Pakistan.
Received: February 29,2020

Published: April 04, 2020

(C) All rights are reserved by Yunis Khushi.
Asian, African, South American and other poor regions of the globe are being extremely overcrowded due to high population growth rate and the material resources of these regions are being choked, which ultimately affects the quality of life for the masses of these regions and is also affecting the health and life span of women of these regions. More than 50 per cent population of these regions does not have basic facilities like potable water, basic education, proper health facilities, proper, decent and suitable housing, decent clothing and nutritional food. The living standards of the people of these regions are very poor and majority of them lives below the poverty line.

There are many factors of high population growth in the abovementioned regions. The most important factor is lack of awareness about the importance of family planning, the hazards and extremely dangerous implications of overpopulation among men and women. Religious views also play a role in promoting overpopulation in poor countries. For example, according to the religious views the growth of population is a sphere controlled by the God/The Creator and men and women must not interfere in this sphere and those who try to control population are sinners. The Islamic view is that every child that comes the world brings his rizq (food and all other needs) with him or her. Also that the controlling population is un-Islamic because the Muslims must increase their population so that on the day of judgement (The last day), the Ummah of the Prophet (the Muslim nation, the followers of the Prophet Mohammed) should be much larger in number than the people of the other religions.

This overpopulation is creating problems for not only development of the poor nations but also has serious implications for the health and life of the women. The women are not allowed to plan their family and they cannot use contraceptives on their own. The uneducated men do not trust their women and do not allow their women to limit the number of children. Thus women become child producing machines and do not have the right to plan or think about their education or career development and are confined to the four walls of the house.
The governments of the countries of these regions must promote education and awareness at the school, college and university level as well as community and village level about the serious dangers of high population growth. Men and women must be taught that it is better to have fewer children and provide them decent living standards rather than having many uneducated and poorly brought up children.

\section{Assets from publication with us}

- Prompt Acknowledgement after receiving the article

- Thorough Double blinded peer review

- Rapid Publication

- Issue of Publication Certificate

- High visibility of your Published work Website: https://www.actascientific.com/ Submit Article: https://www.actascientific.com/submission.php Email us: editor@actascientific.com Contact us: +919182824667 